\title{
Donald Trump's Administration Confronting Missile Defence: Key Challenges and Probabilistic Overview
}

\author{
Grzegorz Nycz \\ Pedagogical University of Cracow \\ e-mail: grzegorz.nycz@up.krakow.pl
}

\section{Abstract}

The text describes main US missile defence efforts in the first years of D. Trump's administration. The analysis of current aspects of BMD (Ballistic Missile Defence) deployments is enhanced by probability analysis examining missile defence reliability. Donald Trump took office in the time of increased military competition between the West and Russia and a dangerous regional crisis related to North Korean nuclear arsenal and its ballistic tests. BMD appeared to bring additional chances to US deterrence options in regional scale, allowing more successful first strike or active defence posture. Notably, D. Trump's administration managed to raise defence expenditures including BMD spending.

Keywords: Donald Trump's administration's security policy, missile defence, probabilistic analysis. 


\section{Introduction}

\section{The progress of US missile defence since the Cold War}

The text focuses on the development of US ballistic missile defence (BMD) ${ }^{1}$ and the significance of regional missile defence cooperation relying on US technologies and leadership (to include the South Korean and Polish perspective). The text aims also to address the Trump administration's policies towards missile threats in the context of technology development and new challenges in the international environment, i.e. dangerous nuclear and ballistic programs of Pyongyang, which created a threat of a regional WMD conflict.

The increased US investments of the 1980s within Ronald Reagan's Strategic Defense Initiative (SDI) brought a concept of an orbital missile defence system, which in a longer perspective would provide a shelter against a massive strategic nuclear strike. In 1989, the US gave up on deploying the SDI, focusing instead on a narrower missile defence system. Alternatives subsequently emerged. The George H. W. Bush administration advocated for Global Protection against Limited Strikes (GPALS) while Bill Clinton modified the design to introduce National Missile Defence (NMD) without space-based interceptors (Baucom, The Rise and Fall of Brilliant Pebbles, 164-65; Baucom, US Missile Defense Program 1944-1994, 27; Dabrowski, 15). In December 2001 the G. W. Bush administration decided to withdraw from an Anti-Ballistic Missile Treaty (ABM) treaty of 1972 in a new security environment after September 11, 2001 terrorist attacks. Bush jr. administration plan of additional sites of a Ground-based Midcourse Defense (GMD) in Eastern Europe (in Poland and Czech Republic) was abandoned by Barack Obama administration in 2009, which reduced earlier plans of GMD deployment in Europe to Aegis Ashore bases in Romania and Poland. Notably, New START agreements signed by the US and Russia in Prague in 2010 were leading to a limitation of deployed strategic warheads of both sides to the level of 1550 for each signatory, on all three legs of strategic triad altogether (DoS b).

The twenty first century's US missile defence was formed on the bases of a longrange intercontinental component (GMD), middle-range naval defence Aegis and terminal stage intercept systems, i.e. upper tier Terminal High Altitude Area Defense (THAAD) and lower tier Patriot Advanced Capability (PAC). The budget appropriations for Missile Defense Agency (MDA), including the preceding

1 Among the bibliography of BMD-oriented research it is worth to note the works of Stephen Cimbala, Andrew Futter, Donald Baucom, Reuben Steff, Ernest Yanarella, Scott McMahon, Dean Wilkening, George Lewis, Catherine Kelleher and Peter Dombrowski, Theodore Postol, James Lebovic, Michael J. Armstrong, as well as (among Polish scholars) of Marek Czajkowski and Tomasz Pugacewicz, a. o. (Cimbala; Futter; Baucom; Steff; Yanarella; McMahon; Wilkening; Lewis; Kelleher, Dombrowski; Postol; Lebovic; Armstrong; Czajkowski; Pugacewicz). 
institutions reached since 1985 to 2017 USD 190 bn (MDA a). After the US left the ABM treaty, MDA received increased funding to the level of circa USD 8 bn annually. The latest progress of intercontinental GMD included the first successful test intercept of an ICBM target on May 30, 2017 (MDA News).

\section{Donald J. Trump and missile defence's budget}

President Donald Trump (promising more funds for stronger BMD, among other Reaganite themes of his presidency) managed to support increased defence budget, growing since he won the race to the White House. Defence expenditures of Trump administration were raised from the level of USD 598.7 bn (USD 593.4 bn in 2016) to USD 643.3 bn in 2018 estimate and USD 688.6 bn in 2019 plan (The White House Office of Management and Budget, 58). The overall MDA funding in 2018-2022 perspective was enlarged from USD 40.9 bn (2018) to USD 47.7 bn in 2019 (MDA b, see table 1).

The total 2019 BMD funding grew to USD 11.5 bn through Congressional action in March 2018 (Judson). MDA's budget in 2018-2023 timeframe plans covered mostly research expenditures on the level of USD 6 bn (see table 1). Those expenses supposed to be a technological hedge against enemy's ICBM (and other ballistic, WMD carriers) progress, as in the case of North Korea. Importantly, 2019 funding was supposed to help to increase GBI number by 20 to 64 due to North Korean proliferation dangers (The White House a 37). Missile defence programs accounted for $5 \%$ of 2019 defence modernization programs i.e. USD 236.7 bn (Comptroller 1).

Table 1. MDA funding 2018-2023 USD millions

\begin{tabular}{|l|r|r|r|r|r|r|r|}
\hline \multicolumn{1}{|c|}{ Year } & 2018 & 2019 & 2020 & 2021 & 2022 & 2023 & Overall \\
\hline $\begin{array}{l}\text { Operations } \\
\text { \& maintenance }\end{array}$ & 504.1 & 496.0 & 502.7 & 535.4 & 525.7 & 567.8 & 3131.7 \\
\hline Procurement & 2417.5 & 2432.0 & 1945.1 & 1669.8 & 1294.9 & 1486.4 & 11245.7 \\
\hline $\begin{array}{l}\text { Research, } \\
\text { development, } \\
\text { evaluation }\end{array}$ & 6798.2 & 6777.3 & 6868.5 & 6878.6 & 6815.4 & 6665.0 & 40803.0 \\
\hline Constructions & 203.0 & 206.2 & 52.2 & 178.0 & 647.5 & 190.8 & 1477.7 \\
\hline Overall funding & 9922.8 & 9911.5 & 9368.5 & 9261.8 & 9283.5 & 8910.0 & 56658.1 \\
\hline
\end{tabular}

Source: MDA b. 


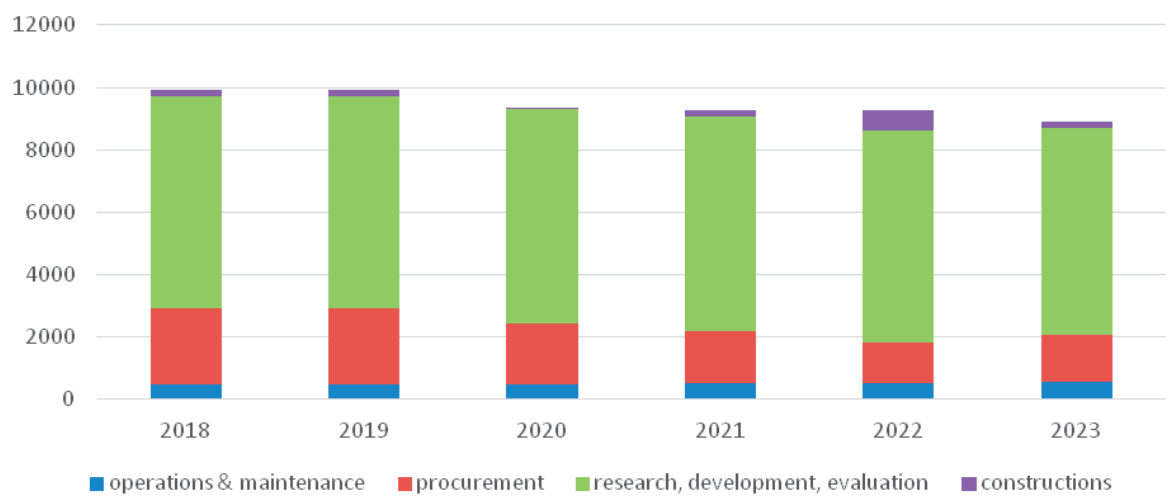

Chart 1. MDA funding in 2018-2023 perspective

Source: MDA b.

MDA director Samuel Greaves in April 2018 justified further increased MDA funding mostly by North Korean threat (Greaves, 1). New technological challenges for US BMD included supersonic-hypersonic cruise missiles launched by rockets, and hypersonic gliders (Greaves, 1). The most important tests planned by MDA in 2019 were European Phased Adaptive Approach (EPAA) phase 3 capabilities and salvo test of GMD (Greaves, 8). Polish Aegis Ashore base built since 2016 was to be delivered by 2020 delayed by two years "due to unsatisfactory rate of construction progress", with a capacity to launch SM-3 Block II, scheduled for deployment in the operational Romanian base (Greaves, 26, 30-31). BMD technology improvements included multi-object kill vehicle (MOKV) for GMD (a program cancelled by Obama administration and reinvigorated after five years) aimed to place more intercepting vehicles in one interceptor to engage more targets (Greaves, 37).

\section{Missile defence in US national security policy under D. Trump}

Key security documents of Trump administration explained the significance of BMD in the light of North Korean threat, as well as Russia's and China's ballistic-nuclear advances. Trump administration's National Security Strategy (NSS) of 2017 mentioned advanced missile proliferation with an eye on North Korea and Iran among main challenges, countered by a new-layered missile defence system developed to protect US homeland (NSS, 3-4, 8, 26). A US BMD response to missile threats from Russia and China (potentially highly dangerous for US command centres and critical infrastructure) was to be limited by requirements of maintaining strategic stability between Washington, Moscow 
and Beijing (NSS, 3-4, 8, 26). National Defense Strategy (NDS) of 2018 distinguished among key international security challenges the ballistic threat of revisionist powers and rogue regimes, such as North Korea and Iran, contained by layered and area BMD (NDS, 2, 6). NDS called for enhanced capabilities of the Joint Force in integrating air and missile defence to counter mobile platforms and an improvement of close combat skills adapted to difficult terrain (NDS, 2, 6).

Nuclear Posture Review (NPR) of 2018 mentioned that Russia was modernizing its older nuclear-tipped BMD and introducing newly designed systems in the field while Russia's political pressure was undermining US missile defence efforts (NPR, 9). Similarly, as NPR stated, China hugely increased its BMD by a future GMD system testing and planned sea-based midcourse and area systems (NPR, 11). US BMD capacities were to strengthen extended deterrence by damage limiting scenarios, introduced among other non-nuclear (conventional deterrence) measures (NPR, 23). In the North Korean case, missile defence in allied cooperation could support first strike options aimed to downgrade Pyongyang's missile attack before it was able to engage targets i.e. "prior to launch" (NPR, 33). Advances in missile defence technologies used by competing powers were justifying further modernization of US strategic triad, including the replacement of Ohio SSBN class (by Columbia class) and Minuteman III ICBM (NPR, 45).

\section{Steps towards Patriot BMD in Poland}

The 2015 Patriot contract with Poland, announced after the public offering was won by Raytheon, included the purchase of US equipment worth USD 2.5 bn within the broader expenses of USD 5 bn on Wisła air and missile defence system, being a part of 10-year program of Polish Armed Forces modernization worth USD 45 bn (DoS a). According to the Polish Ministry of National Defence (MON) the basic task of Polish Patriot would be to counter Russian Iskander (optionally nuclear-tipped) short-range missiles (MON b). Due to Memorandum of Understanding announced in July 2017, the PAC-3 delivery to Poland would begin in 2022, so the missiles could reach operational ability in 2023 (MON c). In November 2017 Defence Security Cooperation Agency (DSCA) announced the approval of Secretary of State to sell to Poland PAC-3 systems (DSCA; Stone). The agreement between Poland and US on Patriot delivery was signed on March 28, 2018. The value of the contract was USD 4.75 bn (the negotiated price was reaching even USD 10.5 bn due to technological requirements) for two batteries with 16 launchers and 208 missiles scheduled on 2022, to be operationally ready between 2023-2024 (MON a; US Embassy). Among 
the controversial issues remained combat effectiveness of PAC units (while its tests results showed $86-88 \%$ reliability). Since the Kuwait war, when the US attempted to upgrade Patriot quickly from air defence weapons to missile defence capacity (to hit Al-Hussein missiles reaching a speed of up to 2200 metres per second) the effectiveness of PAC was put in doubt (McMahon, 297). T. Postol (170) critically claimed that real-time PAC performance at the time was much lower than the official government records.

\section{North Korean crisis}

In the time of Pyongyang's dangerous thermonuclear and ICBM tests, Donald Trump's administration took a difficult attempt to increase pressure on North Korea by stricter sanctions along with broader defence ties with Seoul (including THAAD deployments) and Tokyo, threatened by Pyongyang's aggressive proliferation policies. The analysed scenarios included even a first strike against North Korean nuclear facilities while the US kept all military options opened.

Key North Korean missile accomplishments by 2017 from MDA's perspective included launches of Hwasong-14 ICBM and Hwasong-15 ICBM, as well as Hwasong-12 IRBM (Greaves, 4). The deployment of THAAD battery in South Korea, operational since 2017, was to support the layered missile defence in the region, earlier based on Aegis and PAC (US Army; Choon). Due to US assessments, the sharp PRC's criticism of THAAD in South Korea was based on Beijing's view that the system was de facto aimed at Chinese strategic capacities (Meick, Salidjanova, 3).

Importantly, THAAD battery deployed in Seongju country with a $200 \mathrm{~km}$ range could not intercept all missiles attacking South Korea, including those targeting Seoul, as well as in the case of salvo multiple short-range missile attacks, potentially countered by Patriot and Aegis engagement (Kang). High THAAD reliability according to RAND expert was needed due to the threat posed by North Korean NoDong and medium range Musudan missiles (Bennett).

As Scott Sagan (73) noted, US intelligence data showed that by November 2017 North Korean regime gathered an arsenal of 60 nuclear warheads (while its ability to install them on missiles capable of reaching continental US was questioned) and "window of opportunity" for effective pre-emptive strike stopping Pyongyang's nuclear armaments should be seen as closed.

Ground-breaking compromise on the prospects of the denuclearization after the long crisis appeared possible due to the spirit of Pyongchang Olympics, which opened path to détente. Notably, South Korea's Moon Jae-in skilful diplomacy and surprising Kim Jong-un's willingness to compromise, led to breakthrough declaration on demilitarizing the North's nuclear program, delivered on April 
27, 2018 in Panmunjeom (KOCIS). Notably the June 12, 2018 Singapore summit (Trump-Kim) confirmed the Inter-Korean Panmunjeom declaration on complete denuclearization of the Korean Peninsula (The White House b).

\section{BMD test results and probability analysis}

In March 2018 the overall test reliability of U.S. BMD reached 81.4\%, for all elements effective in 83 out of 102 intercept attempts since 2001 (MDA c). By May 2017 the results of US BMD brought 76 successful intercepts in 93 attempts, including all elements of future layered missile defence system since 2001. The overall test reliability in trials of all components (by mid-2017) reached $81.7 \%$, whereas without PAC-3 (o.862 reliable) the reliability of other components stood at 0.797 including 0.833 for Aegis, 0.55 for GMD and $100 \%$ for THAAD (MDA c). ${ }^{2}$ Only PAC interceptors were combat proven. By mid-2018 PAC-3 effectiveness was raised to $88 \%$, i.e. 30 successes in 34 attempts (MDA d).

Dean Wilkening explained - in reference to J. Bernoulli binomial distribution - the probability $\mathrm{P}(\mathrm{x})$ of defeating the $\mathrm{BMD}$ by $\mathrm{x}$ number of incoming warheads by an equation:

$\mathrm{P}(\mathrm{x})=\left(\begin{array}{c}W \\ x\end{array}\right) q^{x}(1-q)^{W-x}=\left(\begin{array}{c}W \\ x\end{array}\right)\left(1-K_{w}\right)^{x}\left(K_{w}\right)^{W-x}=\frac{W !}{x !(W-x) !}\left(1-K_{w}\right)^{x} K_{w}{ }^{W-x}$

where $\mathrm{K}_{\mathrm{w}}$ meant the (single) probability of detection and interception of an incoming warhead by an interceptor, $\mathrm{W}$ stood for the amount of attacking warheads, in the case of defeating all warheads (and $\mathrm{x}=\mathrm{o}) \mathrm{P}(\mathrm{o})=\left(\mathrm{K}_{\mathrm{W}}\right)^{\mathrm{W}}$ (Wilkening, 187-188).

Table 2. The probability of defeating the missile defence by from 0 to 5 warheads in Bernoulli distribution for interceptors' SSKP $=82 \%$ and a simultaneous attack of 5 warheads (under the conditions of Dean Wilkening's model)

\begin{tabular}{|c|c|c|c|c|c|c|}
\hline $\mathbf{x}$ & $\mathbf{0}$ & $\mathbf{1}$ & $\mathbf{2}$ & $\mathbf{3}$ & $\mathbf{4}$ & $\mathbf{5}$ \\
\hline $\mathrm{P}(\mathrm{x})$ & 0.371 & 0.407 & 0.179 & 0.039 & 0.004 & 0.0002 \\
\hline
\end{tabular}

Source: own counting (using Microsoft Excel) according to an equation $\mathrm{P}(\mathrm{x})=\frac{W !}{x !(W-x) !}\left(1-K_{w}\right)^{x} K_{w}{ }^{W-x}$ based on Dean Wilkening model of Bernoulli distribution (Wilkening, 187-188).

2 BMD without GMD was 0,869 effective by May 2017 (Ibidem). 


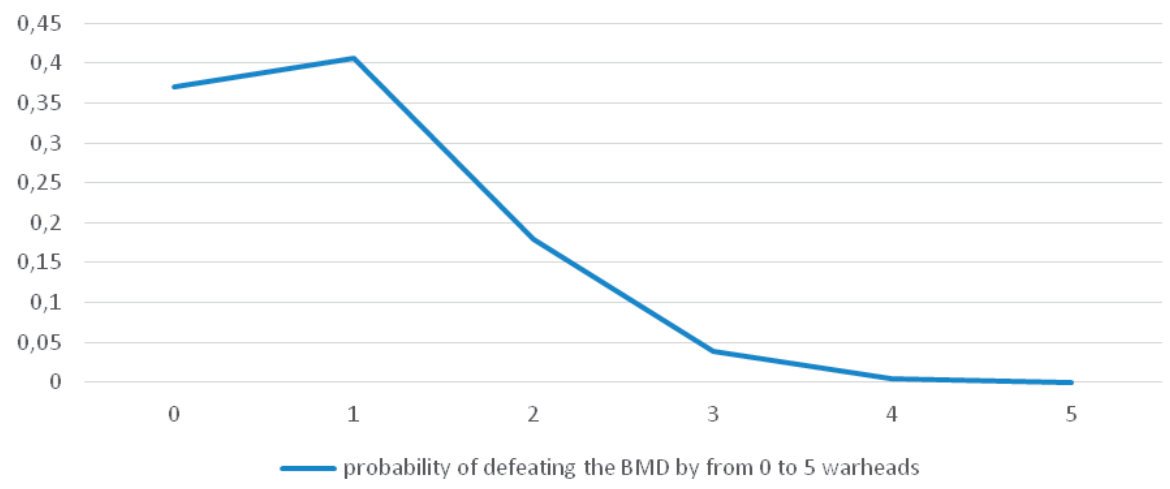

Chart 2. The probability of defeating the missile defence by from 0 to 5 warheads in Bernoulli distribution for interceptors' SSKP $=82 \%$ and a simultaneous attack of 5 warheads Source: as above.

The table and chart show the probability of defeating the BMD by a given amount of attacking warheads (from o to 5) when 5 warheads attack and Single Shot Kill Probability (SSKP), i.e. the likelihood of interception of a single attacking warhead by a single defending missile, reaches $82 \%$. In this case the highest probability $0.41(41 \%)$ is attributed to the outcome of one warhead breaking through the defences, slightly smaller $(37 \%)$ chances are attributed to a full (leakproof) interception, i.e. o warheads would defeat the defence.

Laura Grego, George N. Lewis, David Wright $(1,5)$ referring to earlier Dean Wilkening's model of intercept probability explained the lowering chances of intercept with the increasing number of incoming warheads through an equation:

$$
1-\mathrm{P}(\mathrm{o})=1-\mathrm{p}^{\mathrm{n}}
$$

where $\mathrm{n}$ stands for the number of incoming warheads and $\mathrm{p}$ for a SSKP (interception probability), the right side of an equation shows the probability that at least one of the incoming warheads would defeat the BMD, e.g. for SSKP $=95 \%$ the non-leakproof probability for the attack of 5 warheads reached 0.23 i.e. $1-0.95$. 
Table 3. Test effects of interception (interceptors' SSKP $=82 \%$ ) of 5 warheads (salvo), the probabilities of defeating the BMD by from o to 5 warheads

\begin{tabular}{|c|c|c|c|c|c|c|c|}
\hline distribution & $\begin{array}{c}\mathrm{x}- \\
\text { warheads }\end{array}$ & $\mathbf{0}$ & $\mathbf{1}$ & $\mathbf{2}$ & $\mathbf{3}$ & $\mathbf{4}$ & $\mathbf{5}$ \\
\hline Bernoulli & $\mathrm{P}(\mathrm{x})$ & 0.371 & 0.407 & 0.179 & 0.039 & 0.004 & 0.0002 \\
\hline Poisson & $\mathrm{P}(\mathrm{x})$ & 0.407 & 0.366 & 0.165 & 0.049 & 0.011 & 0.002 \\
\hline
\end{tabular}

Source: own counting (using Microsoft Excel) according to an equation

$\mathrm{P}(\mathrm{x})=\frac{W !}{x !(W-x) !}\left(1-K_{w}\right)^{x} K_{w}{ }^{W-x}$ based on Dean Wilkening model of Bernoulli

distribution (187-188) and

(Poisson distribution), $\mathrm{P}(\mathrm{x})=\frac{\lambda^{\mathrm{k}}}{\mathrm{k} !} \mathrm{e}^{-\lambda}$

The comparison of Bernoulli and Poisson distribution was introduced after Janina Jóźwiak and Jarosław Podgórski (137-139).

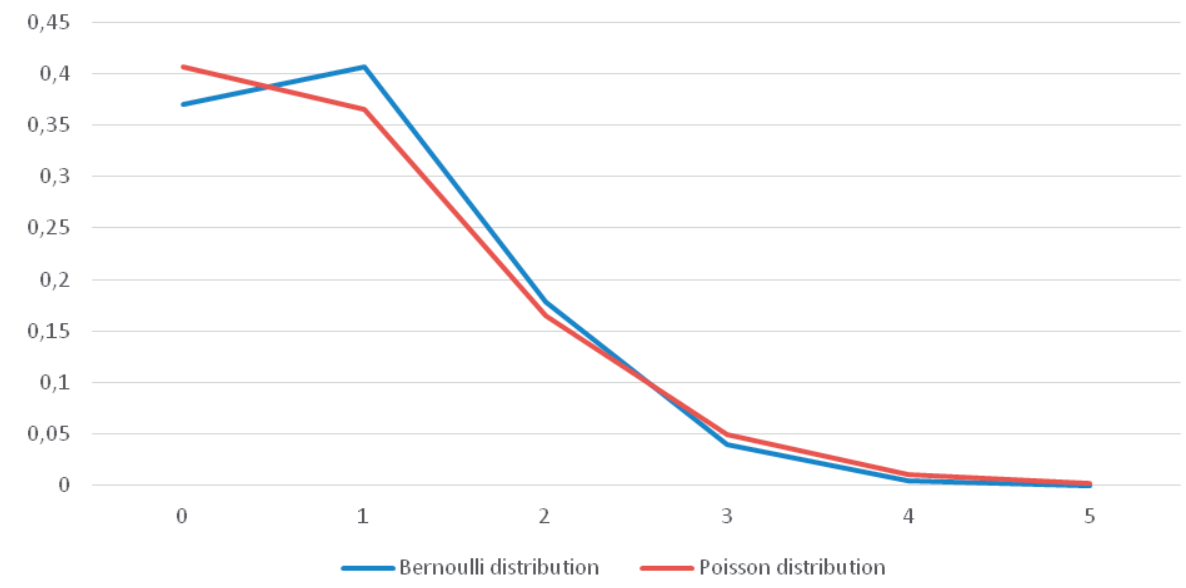

Chart 3. Test effects of interception (interceptors' SSKP $=82 \%$ ) of 5 warheads (salvo fired), the probabilities of defeating the BMD by from o to 5 warheads Source: own counting based on Wilkening model of Bernoulli distribution (187-188), including Poisson distribution example of Jóźwiak and Podgórski (137-139).

The probabilities referring to the $0-5$ warheads defeating the BMD while 5 warheads attacked and SSKP equalled $82 \%$ (close to the mean effectiveness of all US BMD components), signified a small advantage of a probability that one warhead would defeat the defence (over the probability of a leakproof interception) in Bernoulli distribution and slight advantage of a probability of a leakproof interception over a scenario that one warhead would defeat the missile defence system in Poisson distribution. 
Grzegorz Nycz

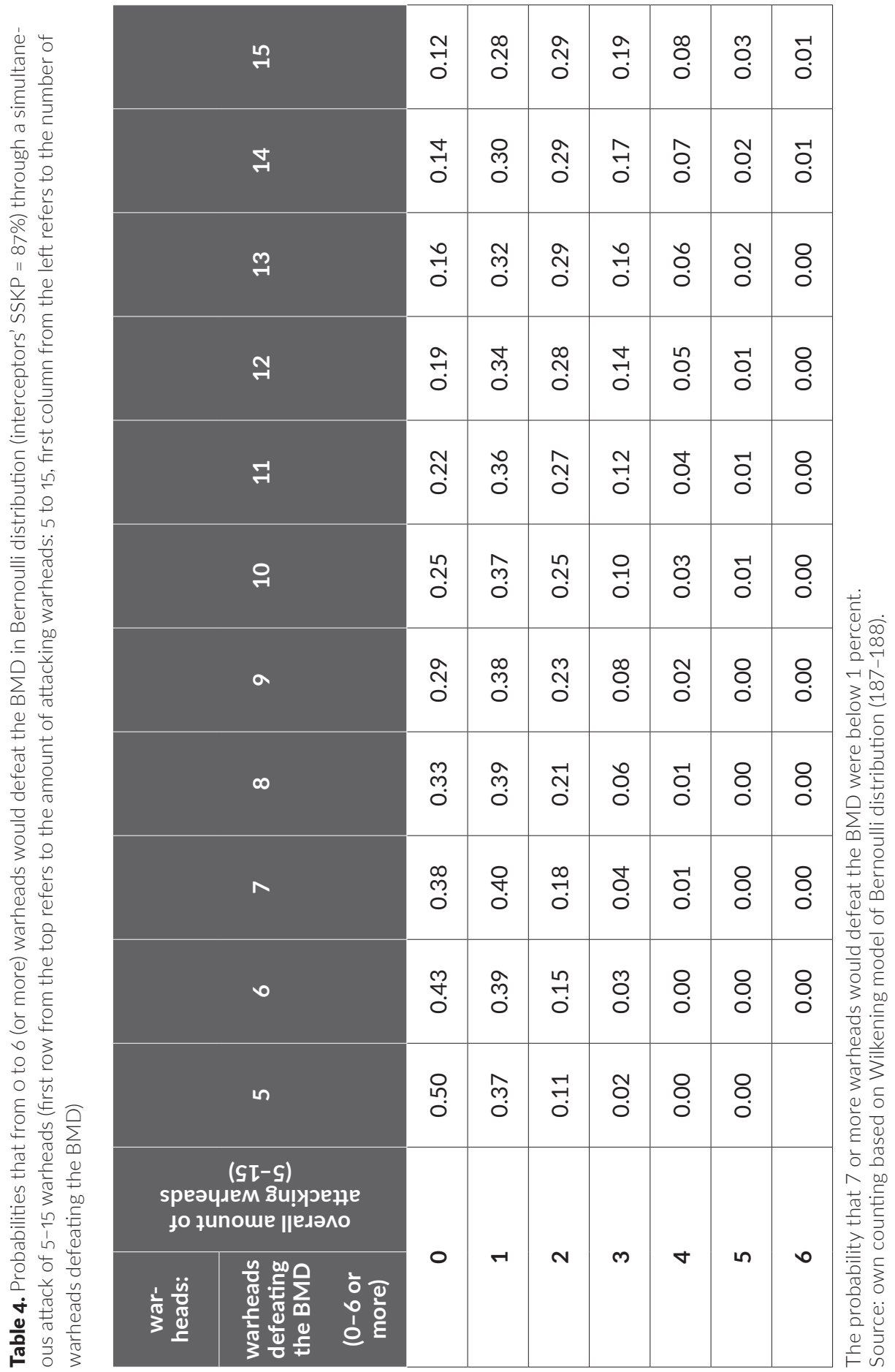


Donald Trump's Administration Confronting Missile Defence...

\begin{tabular}{|c|c|c|c|c|c|c|c|c|c|c|}
\hline 이 & 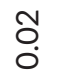 & ô & $\stackrel{n}{\stackrel{n}{\sim}}$ & 호 & $\stackrel{\check{N}}{0}$ & $\stackrel{0}{\stackrel{0}{0}}$ & $\stackrel{\circ}{\stackrel{-}{0}}$ & $\begin{array}{l}\text { LO } \\
\text { ○. }\end{array}$ & $\begin{array}{l}\text { Ō } \\
\text { Oे }\end{array}$ & ○' \\
\hline নे & 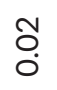 & $\begin{array}{l}\infty \\
\stackrel{0}{0} \\
\stackrel{0}{0}\end{array}$ & $\underset{\circ}{\circ}$ & $\stackrel{\overbrace{}}{\sim}$ & ণั & 웅 & $\begin{array}{l}\text { oे } \\
\text { ò }\end{array}$ & $\begin{array}{l}\text { L } \\
\text { O̊ }\end{array}$ & $\begin{array}{l}\text { Ō } \\
\text { o }\end{array}$ & ơ \\
\hline$\stackrel{\infty}{\sim}$ & 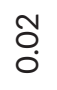 & $\begin{array}{l}\infty \\
\stackrel{0}{0}\end{array}$ & $\stackrel{\sim}{\stackrel{\gamma}{0}}$ & $\underset{0}{~}$ & $\stackrel{ }{0}$ & $\stackrel{n}{\stackrel{n}{r}}$ & $\begin{array}{l}\infty \\
\stackrel{0}{0}\end{array}$ & ঠั & $\begin{array}{l}\text { ণ } \\
\text { ○ }\end{array}$ & 뭉 \\
\hline$\hat{N}$ & 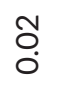 & ò & $\underset{\stackrel{\infty}{\sim}}{\stackrel{\infty}{0}}$ & $\stackrel{\dddot{m}}{0}$ & ণ্ণ & $\underset{\dot{\sigma}}{\stackrel{+}{*}}$ & $\begin{array}{l}\infty \\
\circ \\
0\end{array}$ & mo & ○̊ & 웅 \\
\hline ํำ & O̊ & 엄 & $\stackrel{a}{\stackrel{-}{0}}$ & 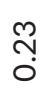 & ণ্ণ & $\stackrel{m}{\stackrel{m}{\circ}}$ & ○ิ & ח̊ & ○ั & ᄋ̊ \\
\hline$\stackrel{\mathscr{N}}{\mathrm{N}}$ & $\begin{array}{l}\text { O̊ } \\
\text { Oे }\end{array}$ & $\stackrel{ }{\stackrel{-}{0}}$ & $\stackrel{ }{\text { N̦}}$ & $\underset{\sim}{\stackrel{\leftarrow}{\sim}}$ & $\stackrel{a}{\stackrel{-}{0}}$ & $\stackrel{\sim}{\sim}$ & $\begin{array}{l}\circ \\
\stackrel{\circ}{\circ}\end{array}$ & $\begin{array}{l}\widetilde{O} \\
\text { Oे }\end{array}$ & ơ & $\begin{array}{l}8 \\
\circ\end{array}$ \\
\hline$\underset{\sim}{\mathbb{N}}$ & \begin{tabular}{l}
\multirow{O}{0}{} \\
$\stackrel{0}{ }$
\end{tabular} & $\stackrel{m}{\stackrel{m}{0}}$ & $\underset{ָ}{ָ}$ & 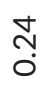 & $\stackrel{a}{\vec{\sigma}}$ & $\stackrel{\overbrace{}}{\stackrel{-}{*}}$ & $\stackrel{\text { Ln }}{\circ}$ & $\begin{array}{l}\text { Ō } \\
\text { Oे }\end{array}$ & ○ั & ৪ \\
\hline $\mathscr{N}$ & $\begin{array}{l}\text { ¿े } \\
\text { ○. }\end{array}$ & $\stackrel{+}{\stackrel{-}{0}}$ & $\stackrel{\text { ָ̦ }}{0}$ & 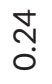 & $\stackrel{\infty}{\stackrel{\infty}{\sim}}$ & $\stackrel{\circ}{\stackrel{-}{0}}$ & $\begin{array}{l}\text { ڤn } \\
\text { O̊ }\end{array}$ & $\begin{array}{l}\widetilde{O} \\
\text { Oे }\end{array}$ & $\stackrel{8}{\circ}$ & \& \\
\hline $\mathbb{N}$ & $\stackrel{\text { In }}{0}$ & $\stackrel{n}{\stackrel{n}{7}}$ & 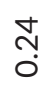 & 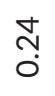 & $\stackrel{ }{\circ}$ & oे & $\begin{array}{l}\text { O̊ } \\
\stackrel{0}{ }\end{array}$ & ö & ৪ & ৪ \\
\hline$\vec{\sim}$ & ○ீ & $\stackrel{\sim}{\stackrel{-}{0}}$ & $\stackrel{\stackrel{n}{N}}{0}$ & 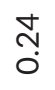 & $\stackrel{\circ}{\stackrel{-}{0}}$ & $\begin{array}{l}\infty \\
0 \\
0\end{array}$ & ח̊ & ণั & ঃ & ○ \\
\hline 오 & ○̊ & $\stackrel{\infty}{\stackrel{\infty}{+}}$ & ָั & 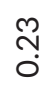 & $\stackrel{n}{\stackrel{n}{\sim}}$ & O̊. & ח̊ํ. & ö & ه̊ & ৪ \\
\hline$\stackrel{9}{a}$ & Ô & ণ্ণ & 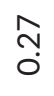 & $\stackrel{\text { N }}{0}$ & $\stackrel{+}{\stackrel{H}{\circ}}$ & $\begin{array}{l}\circ \\
\circ \\
\circ\end{array}$ & 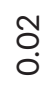 & ○் & $\begin{array}{l}8 \\
\text { ○ }\end{array}$ & $\begin{array}{l}\text { O̊ } \\
\end{array}$ \\
\hline$\stackrel{\infty}{\sim}$ & $\begin{array}{l}\infty \\
0\end{array}$ & $\underset{\text { స̃ }}{0}$ & 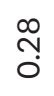 & $\underset{ָ}{ָ}$ & $\stackrel{\sim}{\sim}$ & $\stackrel{\text { L }}{\circ}$ & $\stackrel{\circ}{O}$ & ¿̊․ & ه̊ & ৪ \\
\hline f & ̣̊̊ & $\underset{ }{\stackrel{\nabla}{0}}$ & 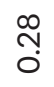 & $\stackrel{ }{0}$ & $\stackrel{\vec{H}}{\circ}$ & ঠ் & ণ̊ & ○ & ৪ & ᄋ \\
\hline$\stackrel{\circ}{r}$ & $\begin{array}{r}\vec{H} \\
\stackrel{-}{0}\end{array}$ & $\stackrel{\circ}{\sim}$ & $\stackrel{\overbrace{}}{\circ}$ & ণั & $\stackrel{\circ}{\stackrel{ }{0}}$ & ঠ̊ & O̊. & 웅 & 웅 & ○ \\
\hline 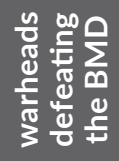 & 0 & $r$ & $N$ & $m$ & $\nabla$ & in & 0 & $\Lambda$ & $\infty$ & $a$ \\
\hline
\end{tabular}


Table 4 and chart 4 show that for five attacking warheads (and interceptors' SSKP $=87 \%$ ) chances of a leakproof interception (o warheads penetrating the defence) stood at $0.50(50 \%)$. There was a $37 \%$ probability that one warhead would break through the defence and $11 \%$ that two warheads would defeat the defence (table 4, column second from the left, under " 5 "). The leakproof intercept probability was obviously decreasing when larger number of warheads attacked simultaneously, i.e. leakproof intercept probability fell to $43 \%$ in a scenario of a defence against six warheads, while under such conditions the probability of one warhead passing through the defence stood at 39\% (table 4, column third from the left, under "6").

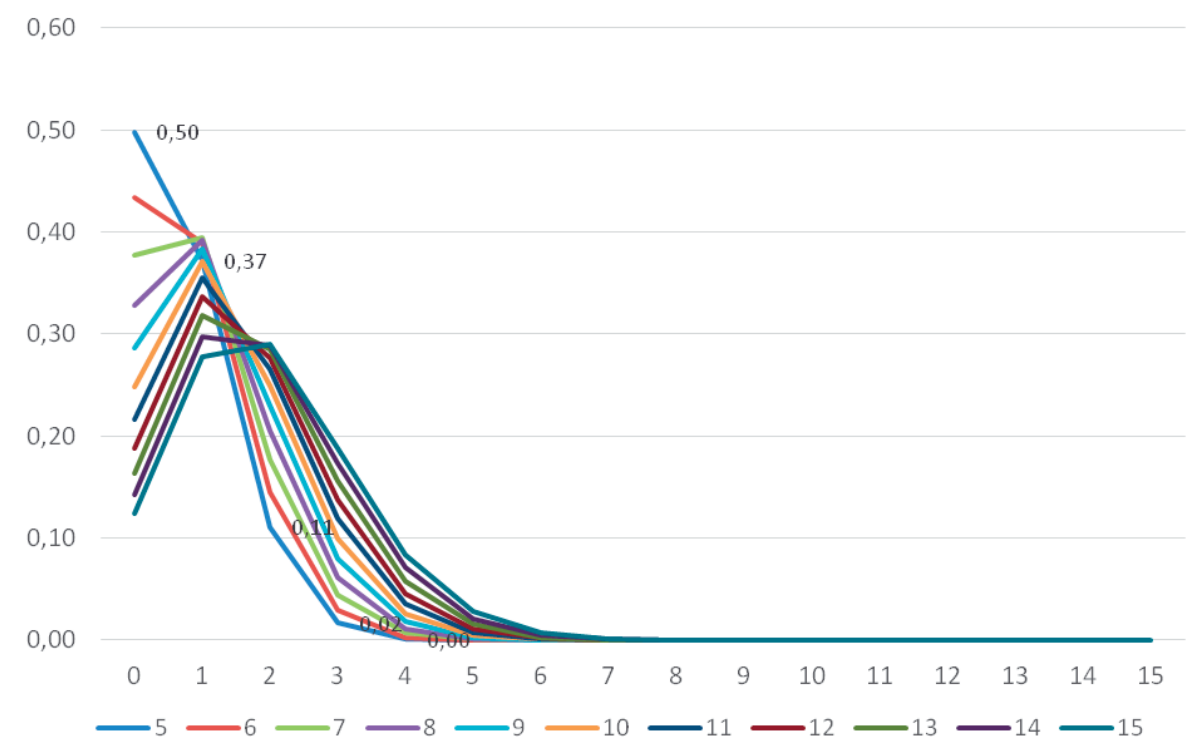

Chart 4. Probabilities (in Bernoulli distribution) that from o to 15 warheads would defeat the BMD (interceptors' SSKP $=87 \%$ ) through a salvo attack of from 5 to 15 warheads Source: as above.

The introduction of additional interceptors could not save the leakproof perspectives under the condition of salvo attack of more than 15 warheads without SSKP improvements, for SSKP at 87\% (see table 6, chart 7). It is noteworthy that it may be more effective to increase SSKP than add more missiles to BMD. 


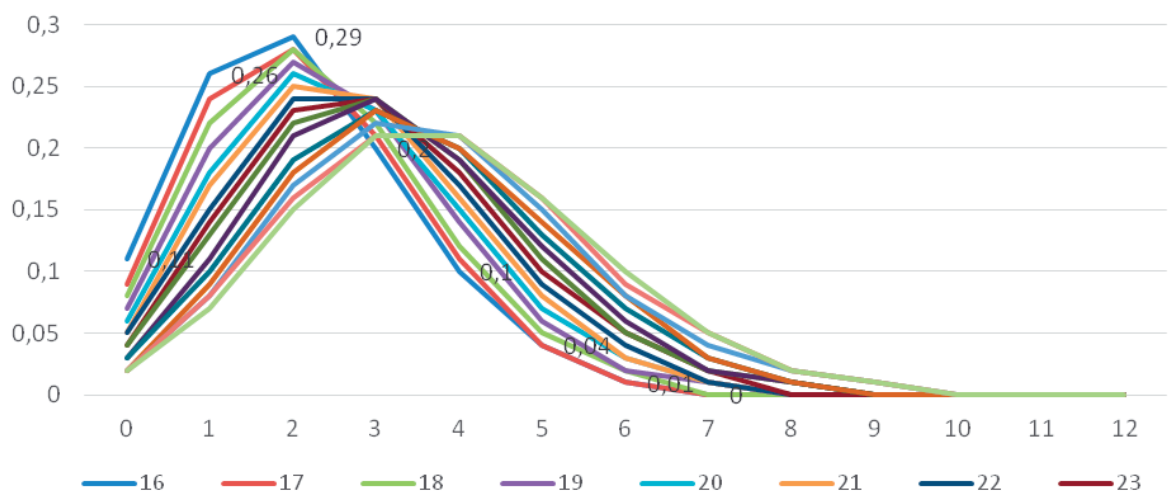

Chart 5. Probabilities that $0-12$ warheads would defeat the BMD (interceptors' SSKP $=87 \%$ ) in Bernoulli distribution, for 16-30 warheads (salvo attack)

The probability that 12 or more warheads would defeat the BMD were below 1 percent. Source: as above.

George N. Lewis explained the layered defence reliability according to the equation showing the probability of a leakproof interception

$$
\mathrm{P}(\mathrm{o})=1-(1-\mathrm{p})^{\mathrm{n}}
$$

where $\mathrm{p}$ stood for SSKP and $\mathrm{n}$ for the number of layers of BMD system, or interceptors (Lewis, 1418-1438). In this analysis (regarding salvo attacks and additional interceptors) in place of SSKP a probability of leakproof salvo interception was used.

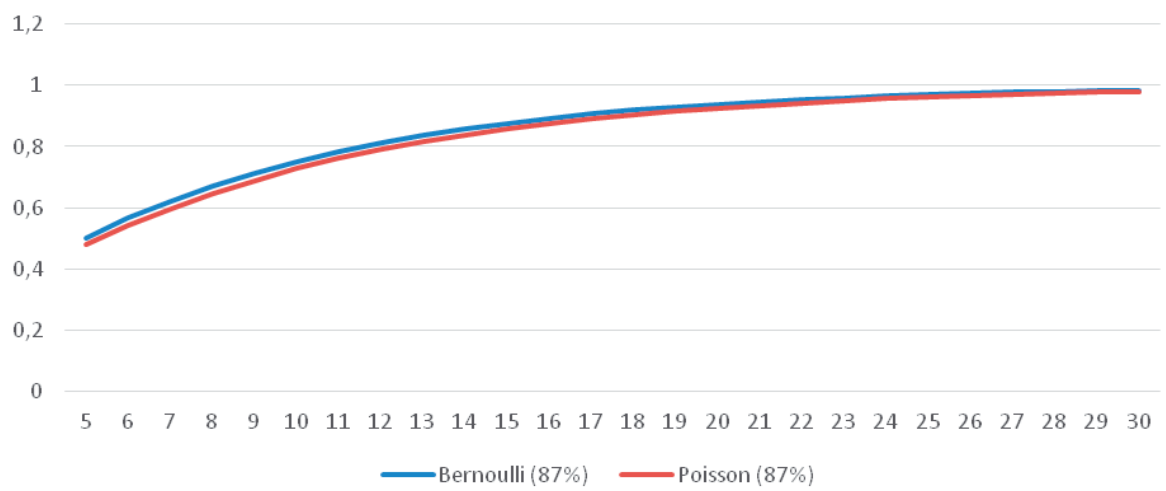

Chart 6. Probability of defeating the BMD (interceptors' SSKP $=87 \%$ ) by 1 or more warheads for 5-30 warheads (salvo attack)

Source: as above. 
Grzegorz Nycz

Table 6. Effects of using additional interceptors (from 2 to 10 against 1 warhead) against from 5 to 30 warheads (salvo attack). Probabilities (in Bernoulli distribution) of a leakproof interception (o warheads defeat the BMD), for the interceptors' SSKP $=87 \%$

\begin{tabular}{|c|c|c|c|c|c|}
\hline $\begin{array}{l}\text { interceptors } \\
\text { warheads }\end{array}$ & 2 & 3 & 4 & 5 & 10 \\
\hline 5 & 0.748 & 0.874 & 0.937 & 0.968 & 0.999 \\
\hline 6 & 0.679 & 0.818 & 0.897 & 0.942 & 0.997 \\
\hline 7 & 0.612 & 0.758 & 0.850 & 0.906 & 0.991 \\
\hline 8 & 0.549 & 0.697 & 0.796 & 0.863 & 0.981 \\
\hline 9 & 0.490 & 0.635 & 0.739 & 0.814 & 0.965 \\
\hline 10 & 0.435 & 0.575 & 0.681 & 0.760 & 0.942 \\
\hline 11 & 0.386 & 0.518 & 0.622 & 0.704 & 0.912 \\
\hline 12 & 0.341 & 0.465 & 0.565 & 0.647 & 0.875 \\
\hline 13 & 0.300 & 0.415 & 0.511 & 0.591 & 0.832 \\
\hline 14 & 0.264 & 0.369 & 0.459 & 0.536 & 0.785 \\
\hline 15 & 0.232 & 0.327 & 0.411 & 0.484 & 0.733 \\
\hline 16 & 0.204 & 0.290 & 0.366 & 0.434 & 0.680 \\
\hline 17 & 0.179 & 0.256 & 0.325 & 0.389 & 0.626 \\
\hline 18 & 0.156 & 0.225 & 0.288 & 0.346 & 0.573 \\
\hline 19 & 0.137 & 0.198 & 0.255 & 0.308 & 0.521 \\
\hline 20 & 0.120 & 0.174 & 0.225 & 0.273 & 0.471 \\
\hline 21 & 0.104 & 0.153 & 0.198 & 0.241 & 0.424 \\
\hline 22 & 0.091 & 0.134 & 0.174 & 0.213 & 0.380 \\
\hline 23 & 0.080 & 0.117 & 0.153 & 0.187 & 0.340 \\
\hline 24 & 0.069 & 0.102 & 0.134 & 0.165 & 0.302 \\
\hline 25 & 0.061 & 0.089 & 0.117 & 0.145 & 0.268 \\
\hline 26 & 0.053 & 0.078 & 0.103 & 0.127 & 0.238 \\
\hline 27 & 0.046 & 0.068 & 0.090 & 0.111 & 0.210 \\
\hline 28 & 0.040 & 0.060 & 0.079 & 0.097 & 0.185 \\
\hline 29 & 0.035 & 0.052 & 0.069 & 0.085 & 0.163 \\
\hline 30 & 0.030 & 0.045 & 0.060 & 0.074 & 0.143 \\
\hline
\end{tabular}

Source: own counting based on Dean Wilkening (187-188) model and $P(0)=1-(1-p)^{n}$ according to George N. Lewis (1418-1438) model. 


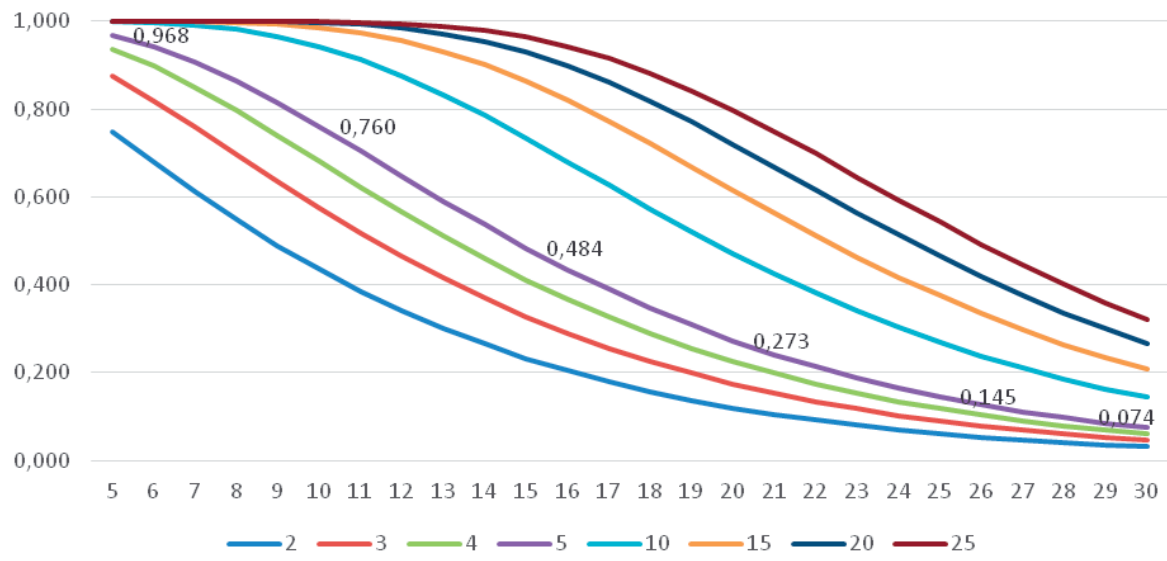

Chart 7. Effects of additional interceptors (from 2 to 25 against 1 warhead) when 5-30 warheads attack: probability of a leakproof interception, SSKP $=87 \%$ Source: as above.

Table 7. Effects of additional interceptors (from 2 to 10 against 1 warhead) when 5-30 warheads attack: probabilities (in Bernoulli distribution) of a leakproof interception for interceptors' SSKP $=93 \%$

\begin{tabular}{|c|c|c|c|c|c|}
\hline warheads & 2 & 3 & 4 & 5 & 10 \\
\hline 5 & 0.907 & 0.972 & 0.991 & 0.997 & 1.000 \\
\hline 6 & 0.875 & 0.956 & 0.984 & 0.995 & 1.000 \\
\hline 7 & 0.841 & 0.937 & 0.975 & 0.990 & 1.000 \\
\hline 8 & 0.806 & 0.915 & 0.962 & 0.983 & 1.000 \\
\hline 9 & 0.770 & 0.890 & 0.947 & 0.975 & 0.999 \\
\hline 10 & 0.734 & 0.863 & 0.929 & 0.963 & 0.999 \\
\hline 11 & 0.698 & 0.834 & 0.909 & 0.950 & 0.997 \\
\hline 12 & 0.662 & 0.803 & 0.886 & 0.934 & 0.996 \\
\hline 13 & 0.627 & 0.772 & 0.861 & 0.915 & 0.993 \\
\hline 14 & 0.593 & 0.740 & 0.834 & 0.894 & 0.989 \\
\hline 15 & 0.560 & 0.708 & 0.806 & 0.872 & 0.984 \\
\hline 16 & 0.528 & 0.676 & 0.777 & 0.847 & 0.977 \\
\hline 17 & 0.498 & 0.644 & 0.748 & 0.821 & 0.968 \\
\hline 18 & 0.468 & 0.612 & 0.717 & 0.794 & 0.958 \\
\hline 19 & 0.440 & 0.581 & 0.687 & 0.766 & 0.945 \\
\hline 20 & 0.414 & 0.551 & 0.656 & 0.737 & 0.931 \\
\hline
\end{tabular}


Grzegorz Nycz

Table 7 (cont.)

\begin{tabular}{|c|c|c|c|c|c|}
\hline warheads & 2 & 3 & 4 & 5 & 10 \\
\hline 21 & 0.388 & 0.521 & 0.626 & 0.707 & 0.914 \\
\hline 22 & 0.364 & 0.493 & 0.596 & 0.678 & 0.896 \\
\hline 23 & 0.341 & 0.465 & 0.566 & 0.648 & 0.876 \\
\hline 24 & 0.320 & 0.439 & 0.537 & 0.618 & 0.854 \\
\hline 25 & 0.299 & 0.414 & 0.509 & 0.589 & 0.831 \\
\hline 26 & 0.280 & 0.389 & 0.482 & 0.560 & 0.807 \\
\hline 27 & 0.262 & 0.366 & 0.455 & 0.532 & 0.781 \\
\hline 28 & 0.245 & 0.344 & 0.430 & 0.505 & 0.755 \\
\hline 29 & 0.229 & 0.323 & 0.405 & 0.478 & 0.727 \\
\hline 30 & 0.214 & 0.303 & 0.382 & 0.452 & 0.700 \\
\hline
\end{tabular}

Source: as above.

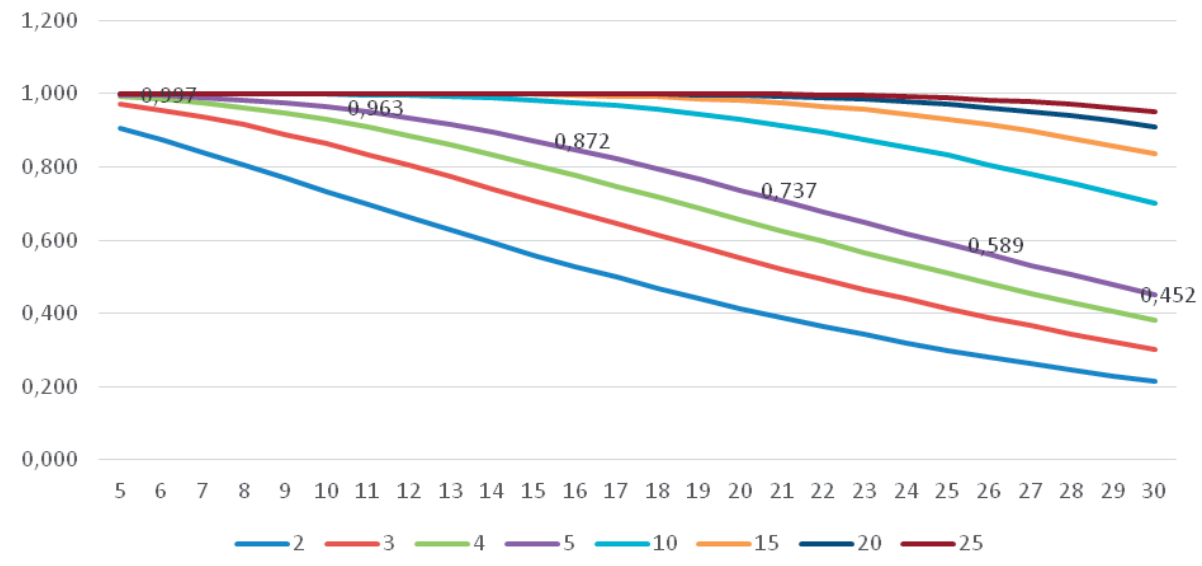

Chart 8. Effects of additional interceptors (from 2 to 25 against 1 warhead) when 5-30 warheads attack simultaneously: probabilities of a leakproof interception for interceptors' SSKP $=93 \%$ Source: as above.

The included tables and charts show the necessity of SSKP improvement (more important than plain adding more BMD missiles) to provide for a leakproof intercept chances in multiple warheads salvo attacks. The probability analysis proves that even a (costly) engagement of 5 and more interceptors against each of salvo attacking warheads for SSKP below $90 \%$ could not secure a leakproof interception (important against WMD threats). As the presented case of $87 \%$-high SSKP (close to PAC-3) shows, even too costly and unrealistic engagement of 10 interceptors against each attacking warhead would not bring a leakproof interception when 
more than 20 warheads attack simultaneously. In this example the rise of SSKP from $87 \%$ to $93 \%$ could improve the leakproof chances intercept higher than proportionally (to SSKP increase). At SSKP level equalling 93\% a hypothetical use of 5 interceptors against each of the warheads attacking simultaneously (a salvo) could provide for a $45 \%$ probability of a leakproof interception in a scenario of a defence against 30 warheads incoming simultaneously while at the SSKP level equalling $87 \%$ the leakproof intercept chances in an analogous case reached only $7 \%$, i.e. 6 percentage points SSKP increase (from 87 to 93) raised leakproof intercept probability by 38 percentage points.

\section{Conclusion}

By the time of Donald Trump's first years in office, the US BMD progress opened a perspective of a low-leaking defence, reaching a reliability above $80 \%$, towards the $90 \%$ level. Nonetheless, the nuclear dimension of threats posed by contemporary dictatorships, most visible in the case of North Korea, led to a verification of predictions of missile defence effectiveness to focus on the chances of leakproof performance (highly important in the case of WMD-tipped warheads). Therefore, the abilities of political mitigation of emerging conflicts related to rogue states equipped with nuclear weapons appear to be conditioned by the capacity of the leading peacekeeper to provide for a leakproof interception. The official state-of-the-arts of BMD technology available by 2017-2018 could bring the partial perspective of terminal leakproof defence through THAAD (with its perfect test results, but no combat experience). Present-day PAC performance still needs to be improved to rely on such an interceptor to provide for a leakproof scenario in the future. The development of GMD' SSKP to high-level performance appears to be more difficult and costly, while it would require a maturing technology of multiple-object kill vehicle, among others, to create future perspective of a defence against decoys released with warheads (MIRV) using low number of GBI's. The present development of Aegis system (after Barack Obama administration cancelled its intercontinental stage) still could not fill a dangerous gap in BMD systems of the US and its allies, weakened in an important dimension by relatively low test results of midcourse defence segment.

\section{Works Cited}

Armstrong, M.J. The Effectiveness of Rocket Attacks and Defenses in Israel. "Journal of Global Security Studies”, no. 3.2 (2018), pp. 113-132.

Baucom, D. The Rise and Fall of Brilliant Pebbles. "The Journal of Social, Political and Economic Studies”, no. 29.2 (Summer, 2004), pp. 143-190. Web. 24 July 2018, 
http://highfrontier.org/oldarchive/Archive/hf/The\%20Rise\%20and\%20Fall\%20 of\%20Brilliant\%20Pebbles\%20-Baucom.pdf.

Baucom, D. US Missile Defense Program, 1944-1994: A Protracted Revolution. Ballistic Missile Defense Organization (February 27, 1995). Web. 24 July 2018, www.dtic. $\mathrm{mil} / \mathrm{dtic} / \mathrm{tr} / \mathrm{fulltext} / \mathrm{u} 2 / \mathrm{a} 338560$.pdf.

Bennett, B. Why THAAD Is Needed in Korea. "The Korea Times" (August, 2017). Web. 25 July 2018, https://www.rand.org/blog/2017/08/why-thaad-is-needed-inkorea.html.

Choon, Ch. 4 more Thaad missile defence launchers to be deployed in South Korea. "The Strait Times" (September 4, 2017). Web. 25 July 2018, http://www.straitstimes. com/asia/east-asia/south-korea-to-announce-approval-of-environment-reportfor-thaad-deployment-on-Monday.

Cimbala, S. Shield of Dreams. Missile Defenses in U.S. and Russian Nuclear Strategy. Annapolis: Naval Institute Press, 2008.

Czajkowski, M. Obrona przeciwrakietowa w stosunkach międzynarodowych. Kraków: Wydawnictwo Uniwersytetu Jagiellońskiego, 2013.

Dabrowski, J. Missile Defense. The First Seventy Years. Missile Defense Agency (August 8, 2013). Web. 25 July 2018, https://www.mda.mil/global/documents/ pdf/first70.pdf.

Defense Security Cooperation Agency (DSCA). Poland - Integrated Air and Missile Defense (IAMD) Battle Command System (IBCS)-enabled Patriot Configuration-3+. (November 17, 2017). Web. 25 July 2018, http://www.dsca.mil/sites/default/files/ mas/poland_17-67.pdf.

Dodge, M. President Obama's Missile Defense Policy: A Misguided Legacy. Heritage Foundation (September 15, 2016). Web. 25 July 2018, http://www.heritage.org/ defense/report/president-obamas-missile-defense-policy-misguided-legacy.

Futter, A. Ballistic Missile Defense and US National Security Policy. Normalisation and acceptance after the Cold War. London: Routledge, 2013.

Greaves, S. Statement Before the House Armed Services Committee. (April 17, 2018). Web. 25 July 2018, https://www.mda.mil/global/documents/pdf/FY19_Written_ Statement_HASC_SFS.pdf.

Grego, L., Lewis, G., Wright, D. Shielded from Oversight. The Disastrous US Approach to Strategic Missile Defense. Union of Concerned Scientists (July 2016). Web. 25 July 2018, http://www.ucsusa.org/sites/default/files/attach/2016/07/Shieldedfrom-Oversight-appendix-8.pdf.

Jóźwiak, J., Podgórski, J. Statystyka od podstaw. Warszawa: Polskie Wydawnictwo Ekonomiczne, 2012.

Judson, J. Congress provides USD3,3 billion boost for missile defense in FY18 spending bill. "Defense News" (March 21, 2018). Web. 25 July 2018, https://www. defensenews.com/land/2018/03/22/congress-provides-33-billion-boost-for -missile-defense-in-fyl8-spending-bill/. 
Kang, Ch. 'THAAD' anti-missile system can't protect South Korea from missile attacks by itself. "CNBC" (September 11, 2017). Web. 25 July 2018, https://www.cnbc. com/2017/09/11/south-korea-missile-defense-thaad-system-cant-do-the-jobalone.html.

Korean Culture and Information Service (KOCIS). Panmunjeom Declaration for Peace, Prosperity and Unification of the Korean Peninsula. (April 27, 2018). Web. 25 July 2018, http://www.korea.net/Government/Current-Affairs/ National-Affairs $/$ view?affairId $=656 \&$ subId $=641$ \&articleId $=3354$.

Lebovic, J. The Law of Small Numbers: Deterrence and National Missile Defense. "The Journal of Conflict Resolution", no. 46.4 (August 2002), pp. 455-483.

Lewis, G. Technical Controversy. Can Missile Defense Work?, [in:] Regional Missile Defense from a Global Perspective, eds. C. McArdle Kelleher, P. Dombrowski. Stanford: Stanford University Press, 2015; Kindle: Loc 1299-1689.

McMahon, S. Pursuit of the Shield. The U.S. Quest for Limited Ballistic Missile Defense. Lanham: University Press of America, 1997.

MDA a. FY 2017 Historical Funds. Web. 25 July 2018, https://www.mda.mil/global/ documents/pdf/FY17_histfunds.pdf.

MDA b. PB 2019-2023 Budget Summary USD Millions. Web. 25 July 2018, https:// www.mda.mil/global/documents/pdf/budgetfy19_summary.pdf.

MDA c. Ballistic Missile Defense Intercept Flight Test Record (as of May 30, 2017). Web. 25 July 2018, https://www.mda.mil/global/documents/pdf/testrecord.pdf

MDA d. Ballistic Missile Defense Intercept Flight Test Record (as of March 2018). (23 March 2018). Web. 25 July 2018, https://www.mda.mil/global/documents/ pdf/testrecord.pdf

MDA News. Homeland Missile Defense System Successfully Intercepts ICBM Target. (May 30, 2017). Web. 25 July 2018, https://www.mda.mil/news/17news0003.html Meick, E., Salidjanova, N. China's Response to U.S.-South Korean Missile Defense System Deployment and its Implications. "US-China Economic and Security Review Commission” (July 26, 2017). Web. 25 July 2018, https://www.uscc. gov/sites/default/files/Research/Report_China\%27s\%20Response\%20to\%20 THAAD\%20Deployment\%20and\%20its\%20Implications.pdf

Ministry of National Defence (MON) a. Umowa na system "Wista” podpisana (28.03.2018). Web. 25 July 2018, http://www.mon.gov.pl/aktualnosci/artykul/ najnowsze/podpisanie-umowy-na-elementy-i-fazy-systemu-wisla-r2018-03-28/

MON b. Memorandum ws. baterii rakiet Patriot (August 6, 2017). Web. 25 July 2018, http://www.mon.gov.pl/aktualnosci/artykul/najnowsze/memorandum-ws-baterii -rakiet-patriot-f2017-07-06/

MON c. Memorandum of Intent Concerning PATRIOT Defense Capabilities. (July, 2017). Web. 25 July 2018, http://www.mon.gov.pl/d/pliki/rozne/2017/07/MOU.pdf. National Defense Strategy (NDS) 2018. Web. 25 July 2018, https://www.defense.gov/ Portals/1/Documents/pubs/2018-National-Defense-Strategy-Summary.pdf. 
National Security Strategy (NSS) 2017. Web. 25 July 2018, https://www.whitehouse. gov/wp-content/uploads/2017/12/NSS-Final-12-18-2017-0905.pdf.

Nuclear Posture Review (NPR) 2018. Web. 25 July 2018, https://media.defense. gov/2018/Feb/02/2001872886/-1/-1/1/2018-NUCLEAR-POSTURE-REVIEWFINAL-REPORT.PDF

Office of the Under Secretary of Defense (Comptroller). Program Acquisition Costs by Weapon System, FY 2019 (February 2018). Web. 25 July 2018, https://comptroller. defense.gov/Portals/45/Documents/defbudget/fy2019/FY2019_Weapons.pdf

Osborn, K. U.S. Missile Defense Prepares for North Korea. Scout Warrior (September 21, 2017). Web. 25 July 2018, https://scout.com/military/warrior/Article/CouldTHAAD-Protect-South-Korea-From-Massive-North-Korean-Missil-105944331

Postol, T. Lessons of the Gulf War Experience with Patriot. "International Security", no. 16.3 (Winter 1991-1992), pp. 119-171.

Pugacewicz, T. Missile Defense Roles in the Post-Cold War US Strategy. "Politeja", no. 50 (2017), pp. 263-293.

Sagan, S. The Korean Missile Crisis. Why Deterrence Is Still the Best Option. "Foreign Affairs" no. 96.6 (Nov/Dec 2017), pp. 72-82.

Steff, Reuben. Strategic Thinking, Deterrence and the US Ballistic Missile Defense Project From Truman to Obama. Farnham: Ashgate, 2013.

Stone, M. et al. Raytheon gets OK for USD10.5 billion Patriot sale to Poland: Pentagon. "Reuters" (November 17, 2017). Web. 25 July 2018, https://www.reuters.com/ article/us-raytheon-poland-patriot/raytheon-gets-ok-for-10-5-billion-patriot-saleto-poland-pentagon-idUSKBN1DH2KQ.

Syring, J. Statement. Senate Appropriations Committee (March 18, 2015). Web. 25 July 2018, http://www.mda.mil/global/documents/pdf/ps_syring_031815_sacd.pdf

The White House a. An American Budget FY2019 (February, 2018). Web. 25 July 2018, https://www.whitehouse.gov/wp-content/uploads/2018/02/budget-fy2019.pdf

The White House b. Joint Statement of President Donald J. Trump and Chairman Kim Jong Un at the Singapore Summit (June 12, 2018). Web. 25 July 2018, https://www. whitehouse.gov/briefings-statements/joint-statement-president-donald-j-trumpunited-states-america-chairman-kim-jong-un-democratic-peoples-republickorea-singapore-summit/

The White House Office of Management and Budget. Historical Tables. (2018). Web. 25 July 2018, https://www.whitehouse.gov/wp-content/uploads/2018/02/histfy2019.pdf

US Army. US to deploy THAAD missile battery to South Korea (2016). Web. 25 July 2018, https://www.army.mil/article/171316/us_to_deploy_thaad_missile_battery _to_south_korea

US Department of State (DoS) a. Office of the Spokesperson, United States Welcomes Polish Missile Defense Tender (April 21, 2015). Web. 25 July 2018, https://2009-2017. state.gov/r/pa/prs/ps/2015/04/240961.htm 
US Department of State (DoS) b. Annual Report On Implementation Of The New Start Treaty (January 2016). Web. 25 July 2018, https://www.state.gov/t/avc/rls/ rpt/2016/255558.htm

US Embassy in Poland. Umowa między USA i Polską na dostawę systemu rakietowego Patriot (March 28, 2018). Web. 25 July 2018, https://pl.usembassy.gov/pl/ patriot_pol

Wilkening, D. A Simple Model for Calculating Ballistic Missile Defense Effectiveness. "Science \& Global Security", vol. 8.2 (1999), pp. 183-215. Web. 25 July 2018, https:// cisac.fsi.stanford.edu/sites/default/files/Simple_Model_for_BMD.pdf

Yanarella, E. The Missile Defense Controversy. Technology in Search of a Mission. Lexington: University of Kentucky Press, 2002.

Grzegorz Nycz - PhD, adjunct professor at the Pedagogical University of Cracow's Institute of Political Science. Graduated from Jagiellonian University and Cracow University of Economics. Ryoichi Sasakawa Young Leaders Fellowship Fund Fellow $2007 / 2008$. His research refers to US security and foreign policy, with a special focus on nuclear deterrence and ballistic missile defense postures. His recent publications include a monography on strategic balance and US national security policy since 1945 to 2015 (published by Pedagogical University of Cracow in 2016) and articles related to ballistic missile defense investments, as well as US military-political engagements in Eastern Europe, Middle East and East Asia in the time of the "New Cold War" between Russia and the West. 